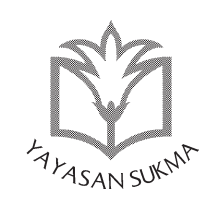

SUKMA: JURNAL PENDIDIKAN

ISSN: 2548-5105 (p), 2597-9590 (e)

Volume 2 Issue 1, Jan-Jun 2018, hlm. 1-24

https://jurnalsukma.org/index.php/sukma/article/view/02101

\title{
DEMOTIVATING FACTORS OF INDONESIAN COLLEGE STUDENTS TO LEARN ENGLISH AS A FOREIGN LANGUAGE
}

\section{Reza Anggriyashati Adara}

Universitas Islam 45 Bekasi, Indonesia

email: reza.adara@gmail.com

\section{Abstract}

Investigating demotivating factors can help teachers to avoid them and provide more insights on sustaining learners'interestin FL learning. The presentstudyaimed to analyse demotivating factors in FL learning. To obtain the findings, the present study applied a mixed method approach. A set of questionnaires adapted from Sakai and Kikuchi's (2009) questionnaires were distributed to thirty eight university students whereas interviews were conducted to three of them. The findings indicated teacher's competence and lack of intrinsic motivation as the most salient factors that caused demotivation 
among the participants. In this consideration, teachers were perceived as incompetent by the participants when teachers have poor English pronunciation and do not provide communicative classrooms. On the other hand, lack of intrinsic motivation was indicated by the loss of students' interest in learning and their goal to be an English speaker. Providing a communicative classroom with a fluent teacher as well as promoting students' interest in English language and culture seem to be the solutions to reduce students' demotivation. [Penelitian tentang faktor-faktor yang menurunkan motifasi (demotivation) dapat membantu para guru untukmenghindarifactor-faktortersebutdan memberikan wawasan untuk mempertahankan minat peserta didik dalam pembelajaran bahasa asing. Penelitian ini menganalisis faktor demotivasi dalam pembelajaran Bahasa asing. Untuk memperoleh jawaban dari beberapa pertanyaan, penelitian ini menerapkan pendekatan metode campuran. Seperangkat kuesioner yang diadaptasi dari model Sakai dan Kikuchi (2009) didistribusikan kepada tiga puluh delapan mahasiswa sedangkan wawancara dilakukan terhadap tiga dari mahasiswa tersebut. Temuan menunjukkan bahwa kompetensi guru dan kurangnya motivasi intrinsik merupakan faktor yang paling menonjol yang menyebabkan demotivasi di antara para peserta. Dalam hal ini, guru dianggap tidak kompeten oleh para peserta ketika guru memiliki pelafalan bahasa Inggris yang buruk dan tidak menyediakan ruang kelas yang komunikatif. Di sisi lain, kurangnya motivasi intrinsik ditunjukkan oleh hilangnya minat siswa dalam belajar dan tujuan mereka untuk berbicara dalam bahasa Inggris. Menyediakan ruang kelas yang komunikatif dengan guru yang fasih serta mempromosikan minat siswa dalam bahasa dan budaya Inggris tampaknya menjadi solusi untuk mengurangi demotivasi siswa] 
Demotivating Factors of Indonesian College Students to Learn English

Keywords: demotivation, demotivating factors, motivation, foreign language learning

\section{A. Introduction}

Investigating demotivation is as important as studying about motivation. While motivation can be considered as one of important factors which sustain learners' interest in FL learning, demotivation is indicated as the opposite of motivation. The previous idea is supported by several studies (Ali and Pathan 2017; Al Khairy 2013; Meshkat and Hassani 2012; Sakai and Kikuchi 2009; Trang and Baldouf 2007). A demotivated learner may lose their interest in FL learning, something that is avoided by teachers. Hence, it is important to examine factors that cause their demotivation in order to prevent it. By understanding those factors, teachers might find solutions to deal with them. Besides that, an interest to study demotivation among foreign language learners might be driven by the possibility of understanding theories of motivation through investigating factors that cause demotivation (Sakai and Kikuchi, 2009). Thus, examining demotivation might help teachers to maintain their students' motivation during the long process of learning FL. It can be said that investigating demotivation is crucial since it helps researchers and educators to avoid it and understand students' motivation better.

Some studies toward demotivation have been conducted to understand the subject. Due to the nature of demotivation as the opposite of motivation, those studies indicate a negative impact of demotivation toward students' results and interest in learning. A study of Trang and Baldauf (2007) pointed out a negative impact of demotivation on students' interest in learning FL as well as preventing them from gaining expected results in learning. Demotivation is also indicated to negatively influence students' learning outcome in a study of Hu (2011). In addition to indicating the effect of demotivation toward students, these studies analyse the factors which cause demotivation among the students. Despite some research of demotivation using various 
groups of learners in various countries, there is lack of studies on demotivation which specifically targets Indonesian students. Beath (2010) emphasizes on the importance of examining motivation of different groups of learners as it might be different depending on the research objects. In line with the present study, investigating demotivation of different groups of learners might provide researchers with better and diverse insights on demotivation. In this consideration, the present study aims to fill the lack of knowledge on Indonesian students' demotivation by investigating factors which cause demotivation among a group of English learners in the university level in Bekasi, Indonesia. The research question of present study is what are the most salient demotivating factors of a group of university students in Bekasi, Indonesia in learning English as a foreign language?

To analyse the above research question, it is imperative to discuss theoretical frameworks of demotivation. Thus, demotivation and previous studies that become the background for the present study will be discussed. Demotivation is an important issue in FL learning. In this sense, demotivation refers to specific drives that diminish motivational reasons (Dörnyei, 2001a, 143). The importance of demotivation is due to its negative effect on students' interest in FL learning. A demotivated learner may gradually lose his or her motivation to learn FL. The latter point is indicated in several studies (Falout and Maruyama, 2004; Kikuchi and Sakai, 2009; Sakai and Kikuchi, 2009). However, Dörnyei (2001a) argued that the presence of demotivation does not always lead to the loss of students' motivation. It is because demotivation is different from amotivation or "the state of lacking intention to act" (Ryan and Deci 2000, 61). Furthermore, Dörnyei and Ushioda (2011) explained that demotivation is caused by specific external sources whereas amotivation is more to learners' realisation that their objectives are unrealistic or not lead to expected outcomes. In this sense, demotivation limits the students' motivation while the other motivational factors that affect students' interest in FL learning are still there (Meshkat and Hassani 2012). In short, students' motivation still exists 
although diminished by demotivating factors. Analysing demotivation might give insights to teachers on how to prevent it among their students. It can be said that the importance of demotivation lies on the way such knowledge might be used to avoid it among the students.

There are many factors which lead to demotivation. These factors have been investigated in numerous studies (Ali and Pathan 2017; Meshkat and Hassani 2012; Rajabi and Pozveh 2016). Negative experiences with teachers, poor school facilities and materials, low self-confidence, bad opinions on the L2 or the L2 culture, negative attitudes of other group members, and the fact that language study is mandatory were few factors identified by Dörnyei (2001a) as the ones that could impede students' motivation. As mentioned in the previous paragraph, Dörnyei and Ushioda (2011) considered external factors as the main causes of demotivation. However, Sakai and Kikuchi (2009) argued that some internal factors such as lack of intrinsic motivation and lack of self-confidence may lead to demotivation. The argument came from several studies which included external and internal sources as the causes of demotivation (Arai 2004; Falout and Maruyama 2004; Kojima 2004; Tsuchiya 2004). Summarizing from previous studies on demotivation, Sakai and Kikuchi (2009) indicated five main demotivating factors; (a) Course Books, (b) Inadequate School Facilities, (c) Test Scores, (d) Non-Communicative Methods, and (e) Teachers' Competence and Teaching Styles. The weight of evidence suggests that both internal and external factors may lead to demotivation.

Relatively compared with motivation in foreign language learning, demotivation might be not as widely investigated. However, some researchers have attempted to investigate the topic in different contexts of learners and teaching location. Applying a quantitative method to obtain its findings, a study of Meshkat and Hassani (2012) used an adaptation of Sakai and Kikuchi's (2009) questionnaire. The participants were 421 high school students in Iran. The findings showed inadequate school facilities, overemphasis on grammar and the long reading texts 
as the main demotivating factors. In addition, a study of Ali and Pathan (2017) also used an adapted version of Sakai and Kikuchi's (2009) questionnaire to obtain their findings. The participants of Ali and Pathan's (2017) study are 150 freshmen from three different disciplines at a university in Pakistan. The findings indicated course content and teaching materials as the most salient demotivating factors. Unlike both previous studies, a study of Aydin (2012) used a qualitative method to investigate factors causing demotivation in EFL teaching process. Using interviews and diary as research instruments, the participant is an EFL teacher in Turkey. The findings showed teaching profession, curriculum, working conditions, and students as few factors causing demotivation. In Indonesian context, there is relatively lack of studies on demotivation. Applying a descriptive quantitative method, a study of Khusyabaroh (2017) on students' perceptions about demotivating factors in learning English indicated teachers, classmates, textbooks and activities, and students' characteristics as the demotivating factors.

Respondents of the present study are thirty eight students of English literature department of Universitas Islam 45 Bekasi. All respondents have studied in English literature department for at least two years. To provide the respondents with more privacy, the survey was conducted anonymously. Thus, the survey was designed without asking any private details of respondents such as their sex or name. The present study applied a mixed method approach. The research instruments used to obtain the findings are a set of questionnaires and interviews.

The questionnaires items were designed to indicate certain factors that influence demotivation among students. Following are the demotivating factors that are analysed in the present study: (a) Course Books, (b) Inadequate School Facilities, (c) Test Scores, (d) Non-Communicative Methods, and (e) Teachers' Competence and Teaching Styles. The questionnaires were distributed via Google forms. On the other hand, interviews were performed by providing respondents with a set of questions that they had to answer the next day. Interviews respondents must 
Demotivating Factors of Indonesian College Students to Learn English

record their answers so that it could be analysed afterward. The maximum period of data collection of the present study was a week. The collected quantitative data was analysed with SPSS whereas qualitative data was transcribed and coded into several categories before they were analysed. The categories in which the interviews' transcript was coded were five factors mentioned above. To provide with more descriptive findings, one factor, demotivation effects was added to the coding category.

\section{B. Results and Discussions}

This section discusses the results of present study. The findings from questionnaires will be discussed whereas the results of interviews will be used to provide further illustration for the discussions. The present study used Sakai and Kikuchi's (2009) five demotivating factors: (a) Course Books, (b) Inadequate School Facilities, (c) Test Scores, (d) Non-Communicative Methods, and (e) Teachers' Competence and Teaching Styles as identification factors.

Figure 1 shows 'teacher's competence' and 'lack of intrinsic motivation' as the most salient demotivating factors of the participants in the present study. They are followed by 'inadequate school facilities', 'test scores', and 'learning content and materials'. Each factor will be discussed in following paragraphs. Unlike the present study, Sakai and Kikuchi's (2009) study indicated

\begin{tabular}{ccccc}
\hline Factor & $\mathbf{N}$ & Mean & $\begin{array}{c}\text { Std. De- } \\
\text { viation }\end{array}$ & Median \\
\hline $\begin{array}{c}\text { F1 (Learning content and mate- } \\
\text { rials) }\end{array}$ & 38 & 3.03 & 0.636 & 3.00 \\
\hline F2 (Teacher's competence) & 38 & 3.97 & 1,052 & 4.00 \\
\hline F3 (Inadequate school facilities) & 38 & 3.92 & 1,024 & 4.00 \\
\hline F4 (Lack of intrinsic motivation) & 38 & 4.03 & 1,026 & 4.00 \\
\hline F5 (Test scores) & 38 & 3.45 & 1,083 & 4.00 \\
\hline
\end{tabular}

Figure 1. Demotivating Factors 
'learning content and materials' as well as 'test scores' as the most salient demotivating factors. Similar results were also shared by the study of Ali and Pathan (2017) which showed 'course content and teaching materials' as the most demotivating factors among the participants. In addition, Rajabi and Pozveh's (2016) study toward a group of EFL learners in Iran showed 'class characteristics and materials' as the most salient demotivating factors.

The differences in the findings of above studies were interesting to be noted as different respondents might experience different demotivating factors. Some factors might contribute to the differences in findings. Firstly, it is interesting to note that there is a similarity among the studies of Ali and Pathan (2017), Rajabi and Pozveh (2016), and Sakai and Kikuchi (2009). Their findings indicate course books as the most demotivating factors. It can be assumed from their findings that most respondents of the previous studies are demotivated because of the 'course books or learning materials'. Related to the present study, learning content and materials become the least factors which contribute to students' demotivation. The present study also shared similar result with Dörnyei (2001a) which indicated course books as the least demotives or demotivating factors.

Figure 2 shows that most lessons given to them are not

\begin{tabular}{cccc}
\hline Factor & Learning Contents and Materials & Mean & Median \\
\hline 3 & $\begin{array}{c}\text { Most of the lessons focused on the } \\
\text { grammars. }\end{array}$ & 2.50 & 2.00 \\
\hline 17 & $\begin{array}{c}\text { English passages in the textbooks } \\
\text { were too long. }\end{array}$ & 3.33 & 3.00 \\
\hline 19 & $\begin{array}{c}\text { I have to read a lot of English text- } \\
\text { books }\end{array}$ & 3.00 & 3.00 \\
\hline 18 & $\begin{array}{l}\text { English sentences dealt with in the } \\
\text { lessons were difficult to interpret. }\end{array}$ & 3.50 & 2.00 \\
\hline 5 & $\begin{array}{l}\text { I was expected to use (or speak and } \\
\text { write) grammatically correct English. }\end{array}$ & 2.25 & \\
\hline
\end{tabular}

Figure 2. Learning Contents and Materials 
too focused on grammar or having too long passages that they have to read. Additionally, most students feel neither they are obligated to read a lot of English textbooks nor expected to use grammatically correct English for written or spoken communication. However, some of them still consider lessons that they dealt with are quite difficult to interpret. The above results indicate that most respondents do not consider their learning content and materials as demotivating. Although it will be far-fetched to assume that the above results indicate the superiority of learning content and materials used to teach the respondents of present study compared to others, it can be said they are not considered too difficult to be understood by the respondents. Sakai and Kikuchi (2009) confirmed that most participants of their study are demotivated because of their course books or lessons that focused on grammar and include long or difficult passages. Similar to the above findings, the findings of Meshkat and Hassani's (2012) study show grammar focused lessons, long reading passages, and the expectancy to use accurate grammar as the most salient demotivating factors. Rajabi and Pozveh (2016) revealed that most participants feel demotivated because their textbooks seem less attractive and less practical than other books they use for other English classes. Besides the above studies, the findings of Ali and Pathan (2017) confirmed that most participants were over burdened with their numerous out-of-date textbooks and supplementary reading assignments. Furthermore, the findings of a study of Yadav and BaniAta (2013) on 100 English department students of a university in Saudi Arabia also indicate the failure of textbooks to capture students' interest due to heavy focus on vocabulary memorization and grammar. The studies of Amemori (2012) toward a group of undergraduate students in Finland and Muhonen (2004) on a group of Finnish English learners also showed course books as the prominent source of demotivation. Besides those studies, Hirvonen's (2010) study on demotivating factors among immigrant students in Finland revealed course contents and teaching materials as one of the most salient demotivating factors. 
There are many factors that can make 'learning contents and materials' to be demotivating to students. As concluded from above paragraph, lessons that focused too much on grammar as well as long or difficult passages may be factors that demotivate students the most. In this regard, some language teaching institutions might provide students with materials that are to the liking of students while others might not. Hence, it seems important to design course books that suit the learners' needs as well as not heavily focused on grammar or long and difficult passages. Peacock (1999) argued that the right use of teaching material can motivate L2 learners to a great extent. Furthermore, Richard and Renandya (2002) support the above statement by addressing a need of L2 learners toward well-designed teaching materials that can maintain students' motivation and improve their interest in learning target language. Thus, providing students with lessons that do not heavily focus on grammar, interesting passages, and suitable with learners' needs might motivate students more and prevent them from being demotivated. Hence, it seems imperative for teachers or language learning institutions to provide learners with 'course books and learning materials' that suit learners' needs. In addition to the above points, a study of Trang and Baldauf (2007) showed that the participants are demotivated with the inconsistent curriculum which caused knowledge gaps among students and made them demotivated. Thus, students need to be provided with consistent curriculum so that they do not have to always adapt with the changes and focus more on studying. It can be said that besides suitable lessons, consistent

\begin{tabular}{clcc}
\hline Factor 3 & \multicolumn{1}{c}{ Inadequate School Facilities } & Mean & Median \\
\hline 21 & Computer equipment was not used. & 3.92 & 4.00 \\
\hline 22 & $\begin{array}{l}\text { Visual materials (such as videos and } \\
\text { DVDs) were not used. }\end{array}$ & 3.75 & 4.00 \\
\hline 23 & The Internet was not used. & 4.17 & 5.00 \\
\hline 24 & LL equipment was not used. & 3.50 & 4.00 \\
\hline
\end{tabular}

Figure 3. Inadequate School Facilities 
curriculum might also contribute to the prevention of demotivation among students.

Although they do not contribute significantly as the most salient demotivating factors of the present study, it is still imperative to analyse inadequate school facilities. It is because the discussion may gain more insights toward demotivation. Figure 3 shows unused internet as well computer facilities as the factors that contribute to students' demotivation the most. Then, they are followed by unused visual materials and unused language learning equipment. Nevertheless, most respondents do not pinpoint inadequate school facilities as the most salient demotivating factors. The study of Kikuchi and Sakai (2009) as well as Sakai and Kikuchi (2009) also indicated 'inadequate school facilities' as the least demotivating factors. These results might be caused by students' satisfaction with existing school facilities. In addition, as mentioned by Kikuchi and Sakai (2009), 'inadequate school facilities' discussed in the questionnaires are only related to multimedia learning environments. Unlike the present study, a study of Sahragard and Alimorad (2013) on 194 Iranian high school students revealed 'inadequate school facilities' as the most demotivating factors among the participants. They elaborated the lack of instructional equipment necessary for improving students' learning in Iranian public schools. Similar to the above study, Meshkat and Hassani (2012) also confirmed 'inadequate school facilities' as the most salient demotivating factors in their study. They point both insufficient school facilities as well as insufficient use of computer facilities by teachers can demotivate students. The aforementioned statement is in line with Young's (2003) findings that confirmed the use of computer facilities in English as foreign language classes as a factor that motivates students. Ayres (2003) argues that students appreciate learning that they do using the computers. Furthermore, Greenfield's (2003) findings show how the majority of participants prefer to study English with computers. It can be said the use of computers in English language classes might motivate students. Thus, the use of computers needs to be promoted to prevent demotivation 
among students.

Besides 'inadequate school facilities', 'test scores' become the one of the least salient demotivating factors. Figure 4 indicates low scores on tests as the most salient reason in this factor. It is followed by students' abilities to perform well on test. Unlike the present study, Sakai and Kikuchi (2009) note 'test scores' as the second most salient demotivating factors. Furthermore, they confirmed that less motivated learners are demotivated with low test scores. Some might argue that only less motivated learners who are demotivated because of low test scores. However, Dörnyei (2001b) argued that poor test results might cause demotivation toward both more and less motivated learners. Thus, he argued that it seems important for teachers to provide encouragement for students when they get low scores in tests. The above argument indicates that levels of motivation may not contribute significantly on students' demotivation when they get low test scores. Nevertheless, it seems imperative to provide motivation to students with low test scores. In addition, as Sawada (2004) suggested, tests need to be designed objectively to show linguistic competence of students. In this sense, tests should include four skills of language (speaking, writing, reading, and listening) so that no students will feel left behind because of their inability to perform tests that mostly focus on writing skills.

The second most salient demotivating factors is 'lack of intrinsic motivation'. Deci and Ryan $(2000,55)$ defined intrinsic motivation as an interest to do something because it is considered

\begin{tabular}{clcc}
\hline Factor 5 & \multicolumn{1}{c}{ Test Scores } & Mean & Median \\
\hline 27 & $\begin{array}{l}\text { I could not do as well on tests as my } \\
\text { friends. }\end{array}$ & 3.67 & 4.00 \\
\hline 8 & $\begin{array}{l}\text { I got low scores on tests (such as } \\
\text { mid-term and final examinations). }\end{array}$ & 3.88 & 4.00 \\
\hline
\end{tabular}

Figure 4. Test Scores 
as interesting or enjoyable. In this sense, an intrinsically motivated learner is interested in learning due to the enjoyment they get from the activity itself and not because of external factors such as grades or rewards. There are many factors that caused the lack of intrinsic motivation among students.

Figure 5 indicates the loss of interest in English as well as the loss of goal to be a speaker of English as the factors that affect their lack of intrinsic motivation to learn English. They are followed by the loss of understanding of studying English and the fact that English was a compulsory subject for them. Unlike the present study, Meshkat and Hassani's (2012) study do not indicate 'lack of intrinsic motivation' as the most salient demotivating factors. A study of Rajabi and Pozveh (2016) also deduced 'lack of interest' as the least demotivating factors. Similar to Meshkat and Hassani (2012), a study of Ali and Pathan (2017) also shows how instrumentally motivated the participants to learn English as they consider it as helpful to achieve significant positions in the society. It can be said that the participants of Ali and Pathan's (2017) study were motivated because they see the benefits of learning English, making lack of intrinsic motivation to be the least demotivating factors for them.

Nevertheless, the studies of Sakai and Kikuchi (2009) revealed 'lack of intrinsic motivation' to be one of the most salient demotivating factors. In addition, a study of Li and Ting (2017) confirmed 'lack of intrinsic motivation' as the most demotivating factor. The findings of Ghadirzadeh and Branch's (2012) study

\begin{tabular}{clcc}
\hline Factor 4 & \multicolumn{1}{c}{ Lack of Intrinsic Motivation } & Mean & Median \\
33 & $\begin{array}{l}\text { I lost my interest in English. } \\
\text { I lost my goal to be a speaker of }\end{array}$ & 4.33 & 5.00 \\
34 & $\begin{array}{l}\text { English. } \\
\text { I lost my understanding of the }\end{array}$ & 4.04 & 4.50 \\
31 & $\begin{array}{l}\text { purpose of studying English. } \\
\text { English was a compulsory subject. }\end{array}$ & 3.67 & 4.00 \\
\end{tabular}

Figure 5. Lack of intrinsic motivation 
also showed almost similar result. Related to the present study, 'lack of intrinsic motivation' might lead to demotivation. Following statement from Student $\mathrm{C}$ indicated the relationship between students' demotivation and lack of intrinsic motivation, "Yes, I do (feel demotivated). If I don't understand several things like the materials or maybe the content." Student C seemed to be less intrinsically motivated when he didn't understand the lesson. However, not all respondents suffered from lack of intrinsic motivation. Student A said that,

I like studying English very much. Both of English (language) and the culture. I think the culture is wonderful and I am so proud of English because English is an international language that (is) used by many people in the world.

Both respondents seemed to differ in terms of intrinsic motivation. Although Student C suffered from lack of intrinsic motivation from time to time, Student A showed high level of motivation to study English. It may be attributed to the characteristics of Student A whom was interested with English language due to its position as an international language as well its culture. It can be concluded from the above statements that students seem to be less demotivated when they are interested with the target language culture. It is similar to the point argued by Sakai and Kikuchi (2009). They maintained that teachers need to motivate students with no goal for being English speakers or do not understand the purpose of learning English. When students know the benefits of learning English, they might be more motivated to learn English, a point shared by the statement made by Ali and Pathan (2017) in the above statement. Similar points were also made by Rajabi and Pozveh (2016) in their study. Furthermore, Li and Ting (2017) asserted that students' interests in English as well as its classes need to be maintained so that they will have clearer goal as language speakers and maintain their efforts to learn English. In this sense, motivating students to learn English can be done by making them interested to its culture and the benefits of studying English. Related to the present study, de- 
motivation level might be minimized when students' interest in English language and culture are promoted. In the near future, there should be study which specifically analyses the relationship between students' lack of intrinsic motivation and demotivation to explain this matter better.

In this study, the first most salient factor is 'teacher's competence and teaching styles'. Figure 6 shows that students seemed to be demotivated the most when teachers shouted or got angry and their English pronunciation was poor. Next, the respondents are demotivated when they are ridiculed for their mistakes. Similar numbers were shared by the items 'teachers only talked in front of the class without looking if students understand the lessons or not' and 'difficult to be understood teachers' explanations'. Last is 'the slow paced lessons' item. The above results show that most respondents seemed to be less motivated to learn English when they are taught by teachers with poor pronunciations. Zhang (2007) also confirmed teachers as the most salient demotivating factors. The findings of Ali and Pathan's (2017) study also indicated teacher's behaviour and poor pronunciation as the most demotivating factors. They suggested the importance of teachers to maintain their behaviour in the classrooms. The point is also

\begin{tabular}{|c|c|c|c|}
\hline Factor 2 & $\begin{array}{l}\text { Teachers' Competence and } \\
\text { Teaching Styles }\end{array}$ & Mean & Median \\
\hline 14 & $\begin{array}{l}\text { Teachers' explanations were not easy } \\
\text { to understand. }\end{array}$ & 3.54 & 3.50 \\
\hline 11 & $\begin{array}{l}\text { Teachers' pronunciation of English } \\
\text { was poor. }\end{array}$ & 3.88 & 4.00 \\
\hline 13 & $\begin{array}{l}\text { Teachers only talked in front of the } \\
\text { class without looking if students un- } \\
\text { derstand the lesson or not. }\end{array}$ & 3.54 & 4.00 \\
\hline 12 & Teachers ridiculed students' mistakes. & 3.71 & 4.00 \\
\hline 15 & Teachers shouted or got angry. & 4.04 & 5.00 \\
\hline 10 & $\begin{array}{l}\text { The pace of lessons was not appropri- } \\
\text { ate. }\end{array}$ & 3.13 & 3.00 \\
\hline
\end{tabular}

Figure 6. Teachers' Competence and Teaching Styles 
shared by the findings of Meshkat and Hassani's (2012) study. Regarding the present study, a respondent showed a tendency of being demotivated with teachers' poor pronunciation. Following is the statement that mentioned such tendency.

They didn't speak English clearly and they spoke in Bahasa Indonesia frequently. If I ever to thought (I asked myself) were they English teachers? If they were English teachers, why they spoke in Bahasa Indonesia in an English course? That made me feels bored. [Student A].

The above statement showed how students might consider their teachers as incompetent when they mostly use first language (L1) instead of target language. The findings of Kikuchi and Sakai (2009) also confirmed that the use of shared L1 by teachers in the classroom made students feel demotivated. It can be said that students might get bored and demotivated due to the frequent use of L1 by teachers. Although it didn't discuss the effect of the use of L1 and its relation with students' motivation or demotivation, a study of Namara (2007) toward the use of L1 in L2 classroom showed that majority of students believed that L2 should be used frequently in the classroom. In the near future, a study toward the relationship between the uses of L1 in EFL classroom and students' motivation might better explain this tendency.

Besides frequent use of L1, the use of non-communicative method by teachers might lead to students' demotivation. Related to the present study, the point can be shown from following statement.

I think my English teacher at the past is less competent because when I was in the class, my teacher just talked what is in the book, didn't give example of others. The learning it was just referring to the book. My teacher just spoke, spoke, spoke and I just listened, listened, and listened but my teacher in college are more competent. They are not give me materials from the book. Sometimes, my teacher asked me to practice so I think it made me can improve my English skill. [Student C] 
The above statement shows how less chance to communicate in target language demotivated students. Yadav and BaniAta (2013) also argued how their participants were demotivated with grammar translation method classes as they give less chance for them to use spoken target language. In addition, Sawada (2004) argued that learners that are taught English by translating written texts might feel unsatisfied with their learning as they do not use English communicatively. Thus, Meshkat and Hassani (2012) In this regard, students seem to be more motivated if they can learn target language communicatively.

Regarding to the present study, Student C also mentioned the difference between her English teachers in the high school and college. While her teachers in high school only gave her materials from the text book, her teachers in the college provided her more materials outside of the text book as well as chances to practice her English. Nevertheless, the findings of Sakai and Kikuchi's (2009) study do not indicate 'teachers' competence' as a significant demotivating factor. However, similar to the findings of present study, Ali and Pathan (2017) suggested a 'one man show' classroom in which students got less chance to speak as demotivating. The findings of Li and Ting's (2017) study also revealed the importance of teachers to pay attention to their teaching methods in order to motivate their students. In this regard, teachers seem to motivate students better when they use communicative teaching methods in the classroom. Similar results were also found in several studies toward demotivating factors (Al Khairy 2013; Kikuchi and Sakai 2009; Rajabi and Pozveh 2016; Yadav and BaniAta 2013).

In this consideration, teachers with less communicative approach might demotivate students more than teachers with communicative approach. Providing more communicative approach in the classroom seems to motivate students as well. Regarding the above points, students' motivation or demotivation seems to be affected by teachers. Student B stated that "I always got a good and professional teacher so I haven't felt less motivated." Contrary to other respondents in this study, Student 
B was never taught by teachers he considered as incompetent to the point he felt demotivated to study English. A study of Lamb (2007) toward students' motivation showed teachers as one of factors that motivate students to study English. It can be said that competent teachers seems imperative to motivate students to learn English.

\section{Limitations and Implications}

Despite the attempt to minimize it, the present study is not one without limitation. First is the size of participants. Although the questionnaires had been spread widely to attract as many as respondents as possible, the current number was still one considered as small. A bigger amount of responses might provide a better representation of the population. Second is the research instruments used in the present study. Although the present study applied a mixed method with questionnaires and interviews as its instruments, more research instruments such as a classroom journal that records students' thoughts toward demotivation and a classroom observation that records students' performance in the classroom might show how demotivation affects students in personal levels. Third is the absence of records toward students' history with demotivation prior to becoming English literature students. Such records might help researchers to know whether demotivation is caused by the course programs or it is something that they have suffered before.

In spite of its limitations, there are some positive implications of the present study. Despite some research toward demotivation in Indonesian context, the number can be considered as lower than ones conducted in other countries such as Japan and USA. The present study provides more insights on demotivating factors, especially ones that affect Indonesian students. Although the present study does not reveal course books as the most salient demotivating factors, the findings indicate the importance of providing course books and learning materials that suit the learners' needs to avoid demotivation among students. In the near future, 
it seems important to conduct a further study that specifically investigates learning materials that contribute to students' demotivation. Such study might help to provide better insights on materials that motivate students the most. Therefore, teachers, language learning institutions as well as course books publishers might provide language learners with course books that do not contribute to students' demotivation as well as suitable for learners' level of proficiency.

Furthermore, the present study showed how teacher's competence influences students' demotivation. Poor pronunciation is shown to be demotivating for students. Teachers should have to be fluent in target language to maintain students' motivation. Teacher training institutions should promote fluency in their recruitment and training programs. Besides being fluent in target language, teachers should promote communicate classroom to motivate their students. In addition to fluency and communicative classroom, teacher's behaviour is indicated to be one that influences students' demotivation. Besides the above points, lack of intrinsic motivation is shown to be one of the most salient demotivating factors. To improve students' intrinsic motivation, teachers can include more materials related to English cultural knowledge or benefits they will get if they are fluent in English so that students will be interested. This point should be mentioned during teacher training or included in the writing process of text book.

\section{Conclusions}

The present study analysed demotivating factors of a group of university students. A mixed method approach was applied to obtain the findings. Research instruments used in the present study are a set of questionnaires adapted from Sakai and Kikuchi's (2009) ones as well as interviews. The participants are thirty eight university students from a private college in Bekasi, Indonesia. The findings showed two most salient demotivating factors; teacher's competence and lack of intrinsic motivation. 
Furthermore, the findings indicated poor pronunciation and lack of communicative approach in the classroom as ones that make teachers seem to be incompetent. On the other hand, lack of intrinsic motivation seemed to be influenced by students' loss of interest in English and goal as an English speaker. To prevent or reduce demotivation among students, teachers should improve their fluency and introduce more topics related to cultural knowledge to improve students' intrinsic motivation. 
Demotivating Factors of Indonesian College Students to Learn English

\section{BIBLIOGRAPHY}

Ali, M.S and Pathan. 2017. "Exploring Factors Causing Demotivation and Motivation In Learning English Language Among College Students Of Quetta, Pakistan." International Journal Of English Linguistics 7 (2): 81-89.

Al-Khairy, M. H. 2013. "English as A Foreign Language Learning Demotivational Factors As Perceived By Saudi Undergraduates." European Scientific Journal 9: 365-382.

Amemori, M. 2012. "Demotivation to Learn English Among University Students in Finland." Masters Thesis.

Arai, K. 2004. "What 'Demotivates' Language Learners? Qualitative Study on Demotivational Factors and Learners' Reactions." Bulletin of Toyo Gakuen University 12: 39-47.

Aydin, S. 2012. "Factors Causing Demotivation in EFL Teaching Process: A Case Study." The Qualitative Report 17 (101): 1-13. Ayres, R. 2002. "Learner Attitudes towards the Use of CALL." Computer Assisted Language Learning 15: 241-249.

Beath, O. 2010. "I Want to Be More Perfect Than Others": A Case of ESL Motivation." Paper Presented at the Faculty of Education and IERI HDR Conference, University of Wollongong, 12 November 2010.

Deci, E. L., and Ryan, R. M. 1985. Intrinsic Motivation and SelfDetermination in Human Behavior. New York: Plenum.

Dörnyei, Z. 1998. "Demotivation in Foreign Language Learning." In TESOL'98 Congress, Seattle, WA.

Dörnyei, Z. 2001a. Teaching and Researching Motivation. England: Longman.

----. 2001b. Motivation Strategies in the Language Classroom. Cambridge University Press, Cambridge.

Dörnyei, Z., and Ushioda, E., 2011. Teaching and Researching Motivation. (2nd Ed.). England: Pearson Longman.

Falout, J., and Maruyama, M. 2004. "A Comparative Study of Proficiency and Learner Demotivation." The Language Teacher 
28: 3-9.

Ghadirzadeh, R and Branch, S. 2012. "Demotivating Factors for English Language Learning Among University Students." Journal of Social Sciences 8 (2): 189-195.

Greenfield, R. 2003. "Collaborative E-Mail Exchange for Teaching Secondary ESL: A Case Study in Hong Kong." Language Learning \& Technology 7: 46-70.

Hamada, Y. 2011. "What Demotivates and What Prevents Demotivation." Annual Research Report on General Education Akita University.

Hirvonen, M. 2010. "Demotivation in Learning English among Immigrant Pupils in the Ninth Grade of Comprehensive School." Master Thesis.

Hu, R. J. S. 2011. "The Relationship Between Demotivation and EFL Learners' English Language Proficiency." English Language Teaching 4 (4).

Kikuchi, K., and Sakai, H. 2009. “Japanese Learners' Demotivation To Study English: A Survey Study." JALT Journal 31 (2): 183.

Kojima, S. 2004. "English Learning Demotivation in Japanese EFL Students: Research in Demotivational Patterns From the Qualitative Research Results of Three Different Types of High Schools." Master Thesis. Hyogo, Japan: Kwansei Gakuin University.

Lamb, M.V. 2007. "The Motivation of Junior High School Pupils to Learn English in Provincial Indonesia." Ph.D. Thesis. University of Leeds.

Li, C and Ting, Z. 2017. "A Questionnaire-Based Study on Chinese University Students' Demotivation To Learn English." English Language Teaching 10 (3): 128-135.

Meshkat, M. and Hassani, M. 2012. "Demotivating Factors in Learning English: The Case Of Iran." Procedia - Social and Behavioral Sciences 31: 745 - 749.

Muhonen, J. 2004. "Second Language Demotivation: Factors That Discourage Pupils From Learning The English Language." Pro 
Gradu Thesis. University of Jyväskylä.

Namara, C. 2007. 'The Use of L1 Support: Teachers' and Students'

Opinions and Practices." The Journal of Asia Tefl 4 (1): 145-178.

Peacock, M. 1999. "Beliefs about Language Learning and Their

Relationship to Proficiency." International Journal of Applied Linguistics 9 (2): 247-263.

Rajabi, B and Pozveh, A. 2016. "A Quantitative Analysis of

Demotivating Factors for Iranian Intermediate High School

EFL Learners." Mediterranean Journal of Social Sciences.

Richards, J. C., and Renandya, W. A. (eds.). 2002. Methodology in

Language Teaching: An Anthology of Current Practice. New York: Cambridge University Press.

Ryan, M. R and Deci, E. L. 2000. "Intrinsic and Extrinsic Motivations: Classic Definitions and New Directions." Contemporary Educational Psychology 25: 54-67.

Sahragard, R., and Alimorad, Z. 2013. "Demotivating Factors Affecting Iranian EFL High School Students" in M. Cortazzi \& L. Jin (eds.). Researching Cultures of Learning. London: Palgrave Macmillan.

Sawada, K. 2004. "What Motivates and Demotivates Learners?." Kansai University Forum for Foreign Language Education 3: 105-112.

Sakai, H., and Kikuchi, K. 2009. "An Analysis of Demotivators in The EFL Classroom." System 37 (1): 57-69.

Trang, T. T. T., and Baldauf Jr, R. B. 2007. "Demotivation: Understanding Resistance to English Language Learning-The Case of Vietnamese Students." The Journal of Asia TEFL, 4 (1): 79-105.

Tsuchiya, M. 2004. "Factors in Demotivation Concerning Learning English: A Preliminary Study of Japanese University Students." The Kyushu Academic Society of English Language Education (KASELE) 32: 39-46.

Yadav, M and Baniata, H. 2013. "Factorizing Demotivation, Finding Motivation: A Constructive Approach to Quality Enhancement." 
Procedia - Social and Behavioral Sciences 70: 120-130.

Young, S. S. C. 2003. "Integrating ICT into Second Language Education an A Vocational High School." Journal of Computer Assisted Learning 19: 447-461.

Zhang, Q., 2007. “Teacher Misbehaviors as Learning Demotivators in College Classrooms: A Cross-Cultural Investigation in China, Germany, Japan, and The United States." Communication Education 56: 209-227. 